\title{
Definition of priority areas for the conservation of a coastal reef complex in the eastern Brazilian coast *
}

\author{
Miguel Loiola $^{\circledR}$, a, b; Igor C. S. Cruz $^{\text {a, c }}$; Zelinda M. A. N. Leão ${ }^{a}$ Ruy K. P. Kikuchi ${ }^{\text {a }}$
}

\begin{abstract}
Coral reef integrity is currently threatened by natural and human activity. The reefs of the eastern Brazilian coast, which stand out as the largest and richest of the South Atlantic Ocean, are not an exception. Tourism exploitation, destructive fishing practices, increased pollution and uncontrolled coastal development are the major human impacts on reefs. The creation of new no-taken zones (NTZs) has thus become an urgent issue because NTZs represent the best measure to guarantee the conservation of reef ecosystems, which are considered biodiversity hotspots. The objective of this work was to define priority areas for implementing NTZs in a coastal reef complex located on the eastern Brazilian coast (southern coast of Bahia State, in the Tinharé Archipelago), which is within an environmental protection area (Tinharé and Boipeba Islands State Environmental Protection Area ['Área de Proteção Ambiental Estadual das Ilhas de Tinharé e Boipeba']). Here we performed a detailed ecological survey of the benthic community in a set of coastal reefs and calculated quantitative conservation priority indices (CPIs) based on ecological attributes associated with the cover of key benthic organisms (corals, macroalgae, filamentous algae, branching and encrusting calcareous algae, sponges and zoanthids) and quantitative indices related to coral species richness and the mean age of the reefs in question. Five coral reefs were classified as high priority for conservation. The large spatial extent of the adjacent fringing reefs of the islands of Tinhare and Boipeba justifies the creation of two rectangular NTZs. We recommend therefore the implementation of two $12 \mathrm{~km}^{2}$ areas spanning two reefs considered of high conservation priority located on the island of Tinharé ("Boca da Barra Norte and Sul") and one reef located on the island of Boipeba ("Ponta dos Castelhanos"). With this design, two of the reefs that were classified as high priority for conservation, "Piscinas de Moreré" and "Tassimirim" (Boipeba), which are extensively used by local populations (for fishing and tourism), would not be covered by the NTZs. The effectiveness of the conservation of these ecosystems also depends on popular acceptance and participation and on combating destructive anthropogenic activities in the region, which include destructive fishing practices and exploratory tourism.
\end{abstract}

Keywords: Coral reefs; Designing protected area; Reef degradation, Conservation plan; No-taken zones.

\section{RESUMO}

\section{Definição de áreas prioritárias para a conservação de um complexo recifal costeiro na costa leste brasileira}

Atualmente a integridade dos recifes de corais está ameaçada por conta de impactos naturais e humanos. Os recifes da costa leste brasileira, que se destacam como os maiores e mais ricos do Oceano Atlântico Sul, não fogem a esta regra. A exploração turística, as práticas de pesca predatória, o aumento da poluição e o desenvolvimento costeiro desordenado representam os principais impactos humanos sobre os recifes. Por conta disso a criação de novas áreas de exclusão de uso (AEUs) se tornaram demandas urgentes e representam a melhor medida para que a conservação desses ecossistemas, considerados como 'hotspots' de biodiversidade, seja garantida. A partir disso o objetivo deste trabalho foi definir áreas prioritárias para a implantação de AEUs em um complexo de recifes costeiros localizado na costa leste brasileira (mais especificamente no litoral sul do estado da Bahia, no Arquipélago de Tinharé), os quais estão dentro dos limites de uma área de proteção ambiental (APA estadual das ilhas de Tinharé e Boipeba). Para tanto, aqui nós realizamos um levantamento ecológico detalhado

\footnotetext{
(a) Corresponding author, to whom correspondence should be addressed.: < miguelloiolam@gmail.com>

${ }^{a}$ Universidade Federal da Bahia, Instituto de Geociências, Grupo de Pesquisa em Recifes de Corais e Mudanças Globais, Rua Barão de Jeremoabo s/n - Campus Universitário de Ondina - CEP 40170-290 Salvador, Bahia, Brasil.

${ }^{\mathrm{b}}$ Universidade Federal do Estado da Bahia, Programa de Pós-Graduação em Ecologia e Biomonitoramento, Rua Barão de Jeremoabo, s/ n, Ondina, CEP 40170-115 - Salvador, Bahia, Brasil.

${ }^{\mathrm{c}}$ Universidade Federal do Estado da Bahia, Programa de Pós-Graduação em Ecologia e Evolução, Rua Barão de Jeremoabo, s/ n, Ondina, CEP 40170-115 - Salvador, Bahia, Brasil.
}

\footnotetext{
* Submission: 29 OCT 2013; Peer review: 4 DEC 2013; Revised: 20 MAR 2014; Accepted: 11 APR 2014; Available on-line: 21 APR 2014
} 
da comunidade bentônica de um conjunto de recifes costeiros e calculamos para cada um destes índices quantitativos de prioridade de conservação (IPC), baseados em atributos ecológicos associados à cobertura de organismos bentônicos chaves (corais, macroalgas, algas filamentosas, algas calcárias ramificadas e incrustantes, esponjas e zoantídeos), e também em indices quantitativos relacionados à riqueza de espécies de corais e à idade média dos recifes em questão. De acordo com o $I P C$, cinco recifes foram classificados como recifes de alta prioridade de conservação. A grande extensão territorial da franja recifal adjacente às ilhas de Tinharé e Boipeba justifica a criação de duas AEUs com formato retangular (formato mais eficiente para esse tipo de unidade de conservação, segundo a literatura especializada). Sugerimos a implantação de duas áreas com $12 \mathrm{~km}^{2}$, abrangendo dois recifes considerados como de alta prioridade de conservação localizados na ilha de Tinharé (Boca da Barra Norte e Sul) e um recife localizado na ilha de Boipeba (Ponta dos Castelhanos). A partir desse arranjo, dois dos recifes classificados como de alta prioridade para conservação, respectivamente Piscina de Moreré e Tassimirim (ambos localizados na ilha de Boipeba), extensivamente usados pelas populações locais (exploração pesqueira e uso turístico), não seriam contemplados pelas AEUs. Ressaltamos que a efetividade da conservação desses ecossistemas depende, também, da aceitação e participação popular e do combate às ações antropogênicas destrutivas, relacionadas na região às práticas de pesca destrutiva e turismo exploratório.

Palavras-chave: Recifes de corais; Criação de áreas marinhas protegidas; Degradação recifal; Plano de Conservação; Áreas de exclusão de uso.

\section{Introduction}

Despite their ecological and economic importance (Connel, 1978; Reaka-Kudla, 1997; Constanza et al., 1997; Moberg \& Folke, 1999; Hughes et al., 2002), coral reefs have declined during the last 50 years as a result of natural and human impacts along coastal areas (Bryant et al., 1998; Aronson \& Precht, 2003; Worm et al., 2006) to such an extent that Bellwood et al. (2004) define the decline as a global crisis for coral reefs. According to Wilkinson (2008), human activities have destroyed $20 \%$ of reefs, while another $35 \%$ are threatened. Given the current state of degradation, several studies suggest that between $20-30 \%$ of coral reefs need to be protected to ensure the conservation of biodiversity and of the resources and services offered (Souter \& Lindén, 2000; Halpern, 2003; Bellwood et al., 2004; Wilkinson, 2004; Roberts, 2003a, 2003b; Wood et al., 2008). Because they harbor a large part of marine diversity, coral reefs should be considered priority areas for conservation (Moberg \& Folke, 1999; Spalding, 2000), and the creation of No-taken zones (NTZs), which prohibit any type of anthropogenic activity, is the best instrument for the protection of these ecosystems (Pandolfi et al., 2003; Aronson \& Precht, 2006; HoeghGuldberg, 2006). Recently, based on the urgent demand for reef conservation, the Great Barrier Reef Marine Park in Australia expanded its NTZs from 4.5\% to 33\% of the reef area (Wilkinson, 2004; Fernandes et al., 2005).

In coral reefs, the exclusion of human use promoted by NTZs allows the recovery and maintenance of ecological integrity (Edmunds \& Carpenter, 2001). A consequence is increased environmental resilience resulting from the recovery and stabilization of populations of functional groups, such as herbivorous and carnivorous fish, which control algae populations capable of eliminating corals by competition and perform top-down control in trophic webs, respectively (Jackson et al.,
2001; Bellwood et al., 2004; Mumbay, 2006; Nystrom, 2006; Moura et al., 2007; Mumbay et al., 2007; Francini-Filho \& Moura, 2008; Nyström et al., 2008). NTZs also facilitate an increase in the number, size and reproductive ability of populations and facilitate the recovery of neighboring environments, serving as natural repositories for the migration of larvae, juvenile and adult organisms (McClanahan et al., 1999; Bellwood et al., 2004; McClanahan, 2006).

The economic importance of coral reefs for much of the coastal population makes it impossible to exclude their use entirely (Kalikoski, 2007). For this reason, studies that aim to select potential sites for the establishment of protected areas should consider a number of criteria designed to reflect the patterns and processes of the environment at a particular scale (Salm et al., 2000). According to Roberts et al. (2003a), the efficiency of a NTZ is related to the integrity of the environment; thus, an area with greater environmental integrity provides more benefits to the environment in general. For marine ecosystems, Salm et al. (2000) together with the International Union for the Conservation of Nature (IUCN) established the following useful criteria for identifying priority areas for conservation: (1) biodiversity, not only of species but also of populations and ecosystems; (2) representativeness, which expresses how the species of a given area reflect the biodiversity of the biogeographical area; (3) the degree of naturalness, which expresses the influence of human interference; (4) the degree of integrity, which indicates the resilience of the ecosystem; (5) the degree of dependency, defined as the importance of a particular area for an adjacent ecosystem; (6) uniqueness, which is the amount of endemism; (7) productivity, which reflects the system's ability to generate and maintain biomass; and (8) vulnerability, which reflects the susceptibility of the system to human activities or stochastic effects.

In Brazil, as in other parts of the world, numerous human impacts threaten the health of coral reefs (Leão \& 
Kiluchi, 2005; Loiola et al., 2013), endangering the goods and services offered, including fish stocks and aesthetic enjoyment through tourism (Constanza et al., 2007), and therefore the viability of coastal communities that rely on the commercial exploitation of reef areas (Kalikoski, 2007; Moura et al., 2007; FranciniFilho \& Moura, 2008). Within the national scenario, the Brazilian east coast brings together the largest and richest coral reefs of the South Atlantic Ocean (Leão et al., 2003), harboring a fauna of corals and fish marked by high rates of endemism (Leão et al., 2003; Moura, 2002). Thus, the east coast of Brazil should be considered as a key area for the conservation of these systems.

In this context, the objective of this work was the ecological description of the benthic community associated with a set of coastal reefs located on the east coast of Brazil, in the south of the state of Bahia (the islands of Tinharé and Boipeba), that are within the limits of a marine conservation unit (State Environmental Protection Area of the Tinharé and Boipeba Islands - 'Área de Proteção Ambiental Estadual das Ilhas de Tinharé e Boipeba'). The most appropriate locations for the establishment of NTZs were identified to ensure the conservation of this group of coastal reefs threatened by uncontrolled urban development. A set of ecological attributes was used to calculate a conservation priority index (CPI) based on criteria including the integrity of the benthic community, the richness of coral species and the reef-building capacity, as defined by Cruz et al. (2013) in a study that choice priority areas for the conservation of the reefs in the Todos os Santos Bay (TSB), Bahia/Brazil. The work aims to provide agencies responsible for managing these reef ecosystems with an unprecedented overview of the status of the coral reefs sampled, indicating possible locations where NTZs can be established, which are hitherto nonexistent in the region (Conder, 1998) and which can serve as repositories of larvae and adults necessary for the preservation and maintenance of stocks of the local marine ecosystem.

\section{Material and methods}

\subsection{Study area}

The study area encompasses a set of coastal reefs located on the southern coast of Bahia, at the islands of Tinharé and Boipeba $\left(13^{\circ} 22^{\prime}\right.$ and $13^{\circ} 40^{\prime} \mathrm{S}$ and $38^{\circ} 51^{\prime}$ and $39^{\circ} 03^{\prime} \mathrm{W}$; Datum SAD 69 ), which are located within a $433 \mathrm{~km}^{2}$ state environmental protection area ('Área de Preservação Ambiental Estadual' [EPA]) consisting of an estuarine ecosystem bordered by coral reefs and seagrass banks. This conservation unit, regulated by the National System of Conservation Units ('Sistema Nacional de Unidades de Conservação' - SNUC), is equivalent to category $\mathrm{V}$ as defined by the
IUCN (Silva, 2005). According to the criteria defined by Salm et al. (2000), reefs in the Tinharé and Boipeba islands are vulnerable to human interference due to exploratory tourism, clearing of mangroves and other riparian vegetation and pollution from domestic sewage. Three of the sampled sites were located on the island of Tinharé, and six were on the island of Boipeba. In Tinharé, the sites included Ilha do Caitá (Caitá $13.3808^{\circ} \mathrm{S}$ and $38.9049^{\circ} \mathrm{W}$ ), Boca da Barra Norte (BBNorte $13.4737^{\circ} \mathrm{S}$ and $38.8973^{\circ} \mathrm{W}$ ) and Boca da Barra Sul (BBSul $13.4841^{\circ} \mathrm{S}$ and $38.9038^{\circ} \mathrm{W}$ ), and in Boipeba, the sites included Tassimirim (Tass $13.5815^{\circ} \mathrm{S}$ and $\left.38,9086^{\circ} \mathrm{W}\right)$, Piscinas de Moreré (PMor $13.5944^{\circ} \mathrm{S}$ and $38.8948^{\circ} \mathrm{W}$ ), Massabuçu (Mass $13.6051^{\circ} \mathrm{S}$ and $38.8979^{\circ} \mathrm{W}$ ), Mateus (Mat $13.6231^{\circ} \mathrm{S}$ and $38.8902^{\circ} \mathrm{W}$ ), Cais (Cais $13.6391^{\circ} \mathrm{S}$ and $38.8893^{\circ} \mathrm{W}$ ) and Ponta dos Castelhanos (PCast $13.6678^{\circ} \mathrm{S}$ and $38.8947^{\circ} \mathrm{W}$ ) (Figure 1).

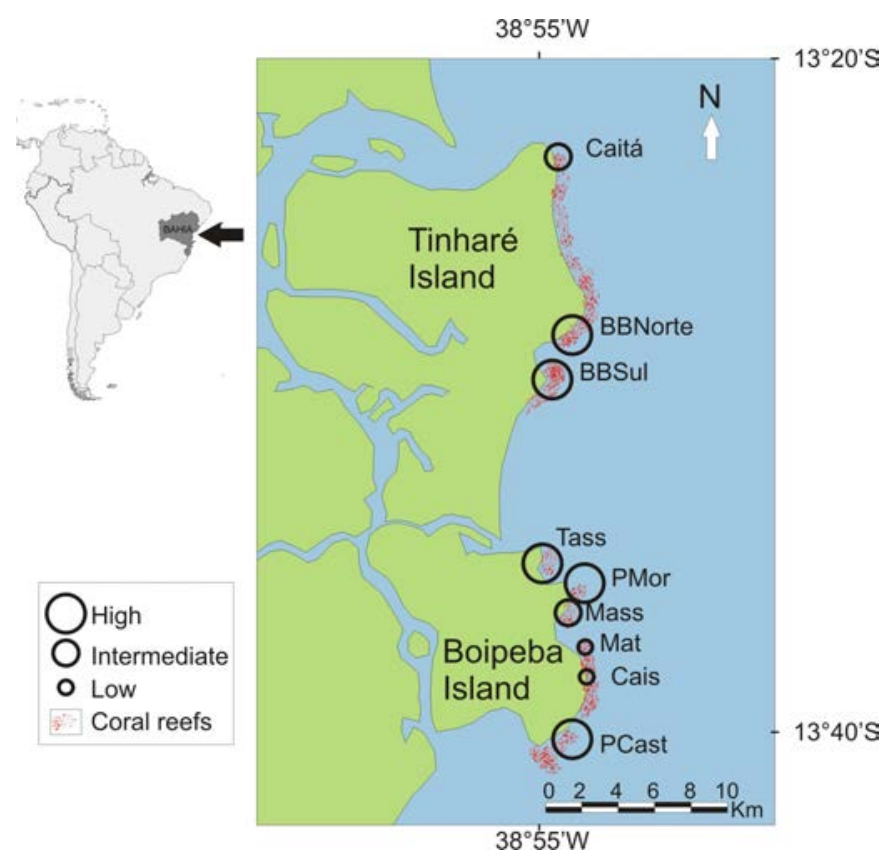

Figure 1 - Location of the Tinharé and Boipeba reefs and sampled stations. Caitá $=$ Ilha do Caitá; BBNorte $=$ Boca da Barra Norte; BBSul = Boca da Barra Sul; Tass = Tassimirim; PMor = Piscinas de Moreré; Mass = Massabuçu; Mat $=$ Mateus and PCast $=$ Ponta dos Castelhanos station.

Figura 1 - Localização dos recifes e das estações de coleta nas ilhas de Tinharé e de Boipeba. Caitá = Ilha do Caitá; BBNorte = Boca da Barra Norte; BBSul = Boca da Barra Sul; Tass = Tassimirim; PMor = Piscinas de Moreré; Mass $=$ Massabuçu; Mat $=$ Mateus e PCast $=$ Ponta dos Castelhanos.

\subsection{Data collection}

Data collection was conducted in January and March 2003, applying the video transect technique (Carleton \& Done, 2001), which consists of filming a strip of the reef substrate with defined dimensions along under 
water line transects using digital video. At each station, six parallel transects were conducted, spaced $10 \mathrm{~m}$ apart. The sampled image area was standardized using a $40 \mathrm{~cm}$ aluminum rod coupled to the filming system. At this distance, the width sampled by the camera is $0.2 \mathrm{~m}$. Each transect was $20 \mathrm{~m}$ long, covering an area of $4 \mathrm{~m}^{2}$, totaling $24 \mathrm{~m}^{2}$ per station. In addition to the video transects, we also collected data on the coral community richness because small species are difficult to identify in the videos (Carleton \& Done, 2001; Cruz et al., 2008).

\subsection{Image processing}

The transects were analyzed by selecting points on successive frames generated throughout the video. Each video transect was separated into 90 frames. Using the program CPCe 3.6, we selected 20 points per frame on an image overlaid with a grid with 450 possibilities. Benthic organisms falling under the randomly selected points were identified. For scleractinians, hydrocorals, zoanthids and octocorals, species-level identification was performed following Laborel (1970) and Hetzel \& Castro (1994), except for the genus Siderastrea due to the difficulty in identifying species of this genus in the field and/or with photography (Neves et al., 2008). In addition to cnidarians, we identified the following groups: macroalgae, filamentous algae, encrusting and articulated calcareous algae (including rhodophytes and Halimeda sp.), sponges, crinoids, sea urchins and sea squirts. Despite being sampled in the videos, the percentages of octocorals, crinoids, sea urchins and sea squirts were not used in the analysis due to the low estimated values for the stations. The results are expressed as the percentage of cover of the groups of organisms. All the coral colonies were grouped into size classes according to Done (1995). The colony size classes varied in 5 centimeter intervals from under $5 \mathrm{~cm}$ to over $30 \mathrm{~cm}$ in diameter. The data were presented as the number of colonies per class per square meter.

\subsection{Conservation priority index (CPI)}

A CPI was calculated for each station following Cruz et al. (2013). The calculation was based on nine ecological attributes estimated from the empirical data collected: (1) index of coral species richness, (2) index of mean coral colony age, (3) percentage of coral cover, (4) percentage of cover of encrusting calcareous algae, (5) percentage of cover of articulated calcareous algae, (6) percentage of cover of macroalgae, (7) percentage of cover of filamentous algae, (8) percentage of cover of sponges and (9) percentage of cover of the zoanthid Palythoa caribaeorum. Table 1 presents the rationale for each of the criteria used. Because of the differences among the units of measurement of each attribute, the scores were converted into dimensionless numbers
(Table 1) so they could be used to create a distinctive CPI for each station, as follows:

$$
\mathrm{CPI}=\mathrm{S}\left(\mathrm{R}_{\mathrm{i}} \times \mathrm{C}_{\mathrm{i}}\right)
$$

where $R_{i}$ is the rank value for the abundance of attribute ' $i$ ' (1-5), and $\mathrm{C}_{\mathrm{i}}$ is the weighting of the ' $\mathrm{i}$ ' attribute based on its ecological role and total abundance in the overall dataset. Therefore, attributes that are functionally important but are rare in the study area, such as the density of coral recruits or the percentage of cover of herbivorous urchins, did not significantly affect the CPI. The $\mathrm{R}_{\mathrm{i}}$ abundance values were therefore progressive (for desirable attributes) or regressive (for the attributes that when significantly abundant are sympto-matically neutral or harmful to reef construction and/or recovery of building corals). Thus, the coral richness, mean colony age and coverage of corals and calcareous algae (encrusting and articulated) were progressive attributes (intervals increasing from 1-5 according to the increase in raw scores), while the coverage of macroalgae, filamentous algae, sponges and zoanthids ( $P$. caribaeorum) were all considered negative attributes (interval classes decreasing from 5 to 1 as the raw value of the scores increases). The per capita weighting of each attribute type was assigned subjectively based on literature reviews, and its $C_{i}$ was calculated as the product of its weight per capita and its global maximum in the sampled dataset. Before being scaled from 1 to 5 , the scores were standardized to a scale of 0 to 100 , which represents the absolute value of benthic coverage for the benthic attributes measured as a percentage of the total cover or a score relative to the maximum value observed for the numerical attributes (such as the index of species richness and the mean age index calculated for the coral colonies).

The species richness index of corals for each station was calculated as follows:

$$
\mathrm{VSR}=\Sigma\left(\mathrm{S}_{\mathrm{i}}\right)
$$

where $S_{i}$ is the proportion of reefs where the species occurs, with 'i' equal to 1 for common species $(>50 \%$ of the stations), 2 for uncommon species (26-50\% of the stations) and 3 for rare species ( $\leq 25 \%$ of the stations). Table 2 present the number of reefs where each coral species was identified and, consequently, the value of each species based on the proportion of reefs where the species occurs.

The index of mean age of coral colonies for each of the stations was calculated as follows:

$$
\mathrm{AA}=\Sigma\left(\mathrm{A}_{\mathrm{i}} \times \mathrm{M}_{\mathrm{i}}\right)
$$

where $A_{i}$ is the mean class ' $i$ ' (in years), and $M_{i}$ is the proportion of individuals in the size class ' $i$ '. The index of age of the corals was estimated from the size of the sampled colonies of species with known annual growth rates, more specifically Mussismilia braziliensis 
Table 1 - Rationale for the use of each of the ecological attributes considered for the calculation of the Conservation Priority Index (CPI). Adapted from Cruz et al. (2013).

Tabela 1 - Justificativa para a utilização de cada um dos atributos ecológicos considerados para o calculo do Índice de Prioridade de Conservação (IPC). Adaptado de Cruz et al. (2013).

\begin{tabular}{|c|c|c|c|c|c|}
\hline Criteria & Justification & Rating & $\begin{array}{l}\text { Maximum } \\
\text { amplitude }\end{array}$ & $\begin{array}{l}\text { Ecological } \\
\text { relevance }\end{array}$ & $\begin{array}{l}\text { Conservation } \\
\text { relevance }\end{array}$ \\
\hline $\begin{array}{l}\text { Species } \\
\text { richness } \\
\text { index }\end{array}$ & $\begin{array}{l}\text { Score both rare species and number of species } \\
\text { (Done, 1995). }\end{array}$ & Progressive & 15,0 & - & 100 \\
\hline $\begin{array}{l}\text { Average } \\
\text { 'age' index }\end{array}$ & $\begin{array}{l}\text { Reflects both the abundance of corals and reef- } \\
\text { building community maturity (Done, 1995), Kyears. }\end{array}$ & Progressive & 157,0 & - & 150 \\
\hline Coral cover & $\begin{array}{l}\text { Corals are the major builders of the reef structure } \\
\text { (Jameson et al., 1998, Knowlton \& Jackson, 2001; } \\
\text { McField \& Kramer, 2007). }\end{array}$ & Progressive & 10,0 & 5 & 50 \\
\hline $\begin{array}{l}\text { Encrusting } \\
\text { calcareous } \\
\text { algae cover }\end{array}$ & $\begin{array}{l}\text { These are reef-building organisms (Knowlton \& } \\
\text { Jackson, 2001) and induce coral recruting (Heyward } \\
\text { \& Negri 1999, Negri et al. 2001). }\end{array}$ & Progressive & 10,4 & 2 & 21 \\
\hline $\begin{array}{l}\text { Articulated } \\
\text { calcareous } \\
\text { algae cover }\end{array}$ & $\begin{array}{l}\text { These algae can be important producers of calcium } \\
\text { carbonate, contributing sediments that fill the pores } \\
\text { of the reef structure (Leão \& Ginsburg, 1997, Leão et } \\
\text { al., 2006). }\end{array}$ & Progressive & 47,6 & 1 & 48 \\
\hline $\begin{array}{l}\text { Macroalgae } \\
\text { cover }\end{array}$ & $\begin{array}{l}\text { Macroalgae are agressive coral competitor (Lirman, } \\
\text { 2001). They are principal causes for the decline of } \\
\text { coral reefs (McCook, 1999; McCook et al., 2001; } \\
\text { Bellwood et al., 2004; Hoegh-Guldberg, 2006). } \\
\text { Cause a permanent stage alternative in reef } \\
\text { community Norström et al., 2009). High abundances } \\
\text { can indicate eutrophication and/or overfishing of } \\
\text { herbivorous fish (Bellwood et al., 2004; Hoegh- } \\
\text { Guldberg, 2006). }\end{array}$ & Regressive & 72,2 & 2 & 144 \\
\hline $\begin{array}{l}\text { Filamentous } \\
\text { cover }\end{array}$ & $\begin{array}{l}\text { These algae are compete with corals (Jompa \& } \\
\text { McCook, 2002; Nugues \& Roberts, 2003), can } \\
\text { disrupt or inhibit coral recruting and may also store } \\
\text { bacteria that are pathogenic for corals (Smith et al., } \\
\text { 2006). }\end{array}$ & Regressive & 28,2 & 1 & 28 \\
\hline $\begin{array}{l}\text { Sponges } \\
\text { cover }\end{array}$ & $\begin{array}{l}\text { Sponges, in addition to eroding reefs (Gly nn, 1997), } \\
\text { can be a coral competitors (Diaz \& Rützler, 2001). } \\
\text { High coverage of sponges characterizes an } \\
\text { alternative stage in reef community (Norström et al., } \\
\text { 2009) and may indicate eutrophication (Diaz \& } \\
\text { Rützler, 2001). }\end{array}$ & Regressive & 7,5 & 2 & 15 \\
\hline $\begin{array}{l}\text { Palythoa } \\
\text { caribeorum } \\
\text { cover }\end{array}$ & $\begin{array}{l}\text { In high abundance they are aggressive competitors of } \\
\text { corals (Tanner, 1997). }\end{array}$ & Regressive & 14,1 & 1 & 14 \\
\hline
\end{tabular}

(6.5 mm), M. hispida $(4.7 \mathrm{~mm})$, M. harttii $(2.1 \mathrm{~mm})$, Montastraea cavernosa $(6.2 \mathrm{~mm})$ and Siderastrea $\mathrm{sp}$. ( $2 \mathrm{~mm})$, as reported by Suggett et al. (2012). Thus, colonies of $M$. cavernosa, Siderastrea sp., M. braziliensis, $M$. hispida and $M$. harttii with a $30 \mathrm{~cm}$ diameter would be approximately 48, 150, 46, 64 and 143 years old, respectively (Cruz et al., 2013).

\subsection{Statistical analysis}

We used non-parametric multidimensional scaling (MDS) to visualize the ordination pattern of the sam pled reefs represented by the percentage of cover of benthic groups, indices of mean colony age and coral species richness.

The MDS plot was subsequently subdivided into three distinct domains associated with the CPI. Thus, three reef categories of high, medium and low conservation priority were identified. The ordination analysis was performed using PRIMER 6.0 (Plymouth Routines in Multivariate Ecological Research) and was based on the Bray Curtis similarity index (Riegl \& Luke, 1998; Clarke \& Warwick, 2001; McField et al., 2001; Khalaf \& Kochzius, 2002). 
Table 2 - Weighting of coral species according to commonness or rarity and the distribution in the study area. For each coral species classified as common (observed in five or more reefs) was attributed a value equivalent to $1 ; 2$ for uncommon species (sampled in 3-5 reefs) and; 3 for rare species (observed in less than 3 reefs).

Tabela 2 - Valor atribuido para cada espécie de coral de acordo com a proporção de recifes de corais onde a mesma é observada. Para cada espécie de coral classificada como comum (presentes em mais do que a metade dos recifes amostrados) foi atribuido um valor equivalente a 1; 2 para as espécies incomuns (presentes entre 5 a 3 recifes) e; equivalente a 3 para as espécies raras (observadas em menos do que três recifes). Adaptado de Cruz et al. (2013).

\begin{tabular}{lccc}
\hline \multicolumn{1}{c}{ Species } & $\begin{array}{c}\text { Number } \\
\text { of sites }\end{array}$ & $\begin{array}{c}\text { Species } \\
\text { Value }\end{array}$ & Total \\
\hline Agaricia agaricites & 9 & 1 & 1 \\
Favia gravida & 9 & 1 & 1 \\
Siderastrea spp. & 9 & 1 & 1 \\
Montastraea cavernosa & 9 & 1 & 1 \\
Mussismilia braziliensis & 9 & 1 & 1 \\
Mussismilia hartti & 7 & 1 & 1 \\
Mussismilia hispida & 9 & 1 & 1 \\
Porites astreoides & 8 & 1 & 1 \\
Porites branneri & 9 & 1 & 1 \\
Scolymia wellsi & 1 & 3 & 3 \\
Millepora alcicornis & 9 & 1 & 1 \\
\hline
\end{tabular}

\section{Results}

\subsection{Characterization of the benthic reef communi- ties}

Sponges and zoanthids were rare overall, with coverage values across the nine stations equal to, or very close to zero (Table 3). Macroalgae showed, almost always, the greatest abundance according to the video-transect data. Only at the PMOR station (Boipeba), with the equivalent of $14.3 \%$ cover, was this class of organisms not the most abundant in terms of percentage of cover. The highest macroalgal cover value was observed at Mateus station on the island of Boipeba, where the organisms covered $72 \%$ of the reef substrate. At the Massabuçu and Cais stations in Boipeba Island and at the Boca da Barra Norte station in Tinharé Island, the macroalgal cover exceeded 50\% (Table 3). Filamentous algae were most abundant at the Ponta dos Castelhanos station (Boipeba), with a cover value of $20 \%$. The lowest value was observed at Cais station, where filamentous algae covered $2 \%$ of the sampled reef area (Table 3 ). Articulated calcareous algae were abundant at the Piscinas de Moreré station, with $48 \%$ cover or double the cover at Ilha do Caitá, which had the second-highest cover value for this class of organisms. Overall, Ilha do Caitá and considerable portion of the reef substrate. Globally, Tassimirim had much higher values than the other stations. Aside from Boca da Barra Sul (Tinharé), with $12 \%$ cover, the other six stations had cover values that did not exceed $5 \%$, with the lowest value observed at Mateus with $1 \%$ articulated calcareous algae cover (Table 3). Encrusting calcareous algae were more abundant at the Piscinas de Moreré, Tassimirim and Ilha do Caitá stations, with values of approximately $10 \%$ cover. At Mateus, this coverage reached $2.5 \%$, and at Ponta dos Castelhanos, encrusting calcareous algal cover was almost zero (Table 3). Coral cover (hard scleractinians and Millepora hydrocorals) was highest at Boca da Barra Norte station, with approximately $10 \%$ of the reef substrate covered by reef-building species. At the Mateus and Cais stations, the coverage values did not exceed 5\% (Table 3 ).

The species abundance patterns of reef-building corals were similar across all the reefs. The species Mussismilia hispida, M. braziliensis and Siderastrea spp. were among the most abundant species together with Montastraea cavernosa, with the exception of the BBNorte and Cais stations (Table 3). These four coral species represented approximately $80 \%$ of the estimated total coral cover. The average coralline cover considering all the stations sampled was equivalent to $5.2 \%$ (including the hard coral order Scleractinia and Millepora hydrocorals).

In total, 11 coral species were observed, with $M$. hispida, M. braziliensis, Montastraea cavernosa, Porites branneri, Agaricia agaricites, Favia gravida, Siderastrea spp. and Millepora alcicornis recorded at the 10 sampled reefs (Table 3).

\subsection{Conservation priority indices (CPIs)}

The values calculated for the conservation priority indices ranged from 97 to 1110 (Table 4). Stations Boca da Barra Norte, Ponta dos Castelhanos, Piscinas de Moreré, Tassimirim and Boca da Barra Sul were considered reefs of high conservation priority according to the attributes defined by Cruz et al. (2013). The two worst indices were calculated for the Mateus (97) and Cais (167) stations. These two reefs were classified as having low conservation priority. The Massabuçu and Ilha do Caitá stations were classified as reefs of intermediate conservation priority. According to the MDS plot, three distinct reef categories were grouped according to the ecological attributes considered (Figure 2).

\section{Discussion}

The reefs studied are characterized by a high percentage of algal cover, especially macroalgae, low percentages of sponge and zoanthid cover and a satisfactory per 
Table 3 - Percent coverage of each benthic group and the most abundant corals. Caitá = Ilha do Caitá; BBNorte = Boca da Barra Norte; BBSul = Boca da Barra Sul; Tass = Tassimirim; PMor = Piscinas de Moreré; Mass = Massabuçu; Mat = Mateus and PCast $=$ Ponta dos Castelhanos station.

Tabela 3 - Percentual de cobertura para cada um dos grupos bentônicos considerados e para as espécies de corais mais abundantes. Caitá = Ilha do Caitá; BBNorte = Boca da Barra Norte; BBSul = Boca da Barra Sul; Tass = Tassimirim; PMor = Piscinas de Moreré; Mass = Massabuçu; Mat = Mateus e PCast = Ponta dos Castelhanos.

\begin{tabular}{|c|c|c|c|c|c|c|c|c|c|}
\hline \multirow{2}{*}{$\begin{array}{c}\text { groups of } \\
\text { organisms }\end{array}$} & \multicolumn{9}{|c|}{ sampled reefs } \\
\hline & Caitá & BBNorte & BBSul & Tass & Pmor & Mass & Mat & Cais & Pcast \\
\hline Macroalgae & 41,70 & 54,54 & 32,89 & 29,52 & 14,26 & 54,93 & 72,18 & 65,94 & 47,74 \\
\hline Filamentous algae & 6,53 & 5,71 & 18,59 & 15,88 & 10,51 & 16,06 & 9,38 & 2,92 & 20,40 \\
\hline $\begin{array}{l}\text { Incrusting } \\
\text { calcareous algae }\end{array}$ & 23,41 & 4,22 & 12,43 & 20,77 & 47,61 & 4,64 & 1,23 & 2,78 & 3,73 \\
\hline $\begin{array}{c}\text { Articulated } \\
\text { calcareous algae }\end{array}$ & 9,04 & 5,45 & 10,17 & 9,70 & 10,42 & 5,73 & 2,77 & 5,51 & 0,19 \\
\hline Sponge & 0,52 & - & 0,02 & 0,23 & 0,01 & 0,02 & 0,04 & - & 0,26 \\
\hline Zoanthid & - & 0,72 & - & 8,03 & - & - & - & - & - \\
\hline Coral & 4,81 & 9,70 & 7,11 & 5,51 & 5,39 & 5,66 & 1,49 & 4,17 & 6,81 \\
\hline $\begin{array}{c}\text { Montastraea } \\
\text { cavernosa }\end{array}$ & 1,94 & - & 0,68 & 0,52 & 1,40 & 0,68 & 0,05 & - & 0,50 \\
\hline Mussismilia hispida & 0,22 & 2,03 & 5,66 & 0,40 & 2,99 & 1,57 & 1,02 & 1,43 & 2,37 \\
\hline Mussismilia harttii & 0,22 & 0,10 & 0,35 & 0,10 & 0,06 & 0,04 & - & - & 1,05 \\
\hline $\begin{array}{l}\text { Mussismilia } \\
\text { braziliensis }\end{array}$ & 0,03 & 0,55 & 0,23 & 0,27 & 0,81 & 0,10 & 0,30 & 0,82 & 0,48 \\
\hline Siderastrea spp. & 0,21 & 6,74 & 0,13 & 1,05 & 0,13 & 3,01 & 0,12 & 0,40 & 2,24 \\
\hline Porites astreoides & - & 0,28 & - & 0,07 & - & 0,26 & - & 0,29 & 0,12 \\
\hline $\begin{array}{l}\text { Millepora } \\
\text { alcicornis }\end{array}$ & 2,19 & - & 0,06 & 3,10 & - & - & - & 1,23 & 0,05 \\
\hline
\end{tabular}

Note 1: The coral species Porites branneri, Agaricia agaricites and Favia gravida (founded in all sampled stations) and Scolymia wellsi (only in Ponta dos Castelhanos reef) are not present in this table because of they small value of coverage (approximatelly zero).

Note 2: Despite showed null values of coverage in BBNorte and Cais reefs, Montastraea cavernosa was observed in these two sampled stations. The same can be said for the fire coral Millepora alcicornis, observed in BBNorte, PMor, Mass and Mat reefs.

centage of coral cover. Algae naturally occupy a considerable portion of the reef substrate. Globally, algal cover, particularly macroalgae, has increased dramatically in many reefs in response to environmental impacts, such as global warming, decreasing water quality (increased sedimentation and nutrient enrichment) and decreasing biomass of herbivorous organisms (McCook, 1999; McCook et al., 2001; Jompa \& McCook, 2002).

The consequence of dramatic increases in algae abundance on reefs is the emergence of phase shifts in which the algae, which include competitor, tolerant and nonreef-building organisms (with the exception of encrusting calcareous algae), tend to cover corals, directly affecting the construction of the reef structure and hence the associated biodiversity (McCook, 1999; Lirman, 2001; Nughes, 2002; Nughes \& Roberts, 2003; Nughes et al., 2004). The values observed for the coral commu nities reflect the pattern of Brazilian reefs, which are usually characterized by low abundance percentages and low richness (Leão et al., 2003) compared, for example, to Caribbean and Indo-Pacific reefs (ReakaKudla, 1997; Hughes et al., 2002).

The reefs studied are within the geographic boundaries of an environmental protection area (Tinharé and Boipeba Islands EPA), the implementation of which was aimed to protect an area of significant environmental value, aligning development with environmental conservation of the area, with the objective of improving the quality of life of local populations and promoting adequate protection of the ecosystems for the permanent and sustained enjoyment of present and future generations (Conder, 1998). Fragments or remnants of tropical forest, sandbanks, mangroves and coral reefs are among the most appealing ecosystems for conservation within this EPA. These landscapes, among oth 
Table 4 - Estimated values and assigned scores for each of the criteria (coverage of benthic key organisms, species richness of corals and average age of reef systems) used for the calculation of conservation priority indexes (CPIs) for each coral reef. CPIs were calculated from the sum of the three scores assigned for each one of the criteria. Caitá = Ilha do Caitá; BBNorte = Boca da Barra Norte; BBSul = Boca da Barra Sul; Tass = Tassimirim; PMor = Piscinas de Moreré; Mass = Massabuçu; Mat $=$ Mateus and PCast $=$ Ponta dos Castelhanos station

Tabela 4 - Valor estimado e pontuação atribuida para cada um dos critérios considerados (percentuais de cobertura dos grupos bentônicos, riqueza de espécies de corais e valor de idade média recifal) para o cálculo dos índices de prioridade de conservação (IPCs) dos recifes. IPCs foram calculados a partir do somatório das três pontuações referentes a cada um dos critérios considerados. Caitá = Ilha do Caitá; BBNorte = Boca da Barra Norte; BBSul = Boca da Barra Sul; Tass = Tassimirim; PMor = Piscinas de Moreré; Mass = Massabuçu; Mat = Mateus e PCast = Ponta dos Castelhanos.

\begin{tabular}{|c|c|c|c|c|c|c|c|c|c|c|c|}
\hline & & & Coral & Macroalgae & $\begin{array}{c}\text { Filamentous } \\
\text { algae }\end{array}$ & $\begin{array}{l}\text { Crustose } \\
\text { coraline } \\
\text { algae }\end{array}$ & $\begin{array}{l}\text { Artuculate } \\
\text { coraline } \\
\text { algae }\end{array}$ & Sponge & $\begin{array}{c}\text { Palythoa } \\
\text { caribaeorum }\end{array}$ & Richness & $\begin{array}{c}\text { Average } \\
\text { 'age' } \\
\text { index }\end{array}$ \\
\hline $\begin{array}{l}\text { Conservation } \\
\text { Relevance }\end{array}$ & & & 42 & 116 & 17 & 10 & 46 & 1 & 8 & 100 & 150 \\
\hline Rating & & & Progressive & Regressive & Regressive & Progressive & Progressive & Regressive & Regressive & Progressive & Progressive \\
\hline Sites & $\begin{array}{l}\text { Conservation } \\
\text { Priority Index }\end{array}$ & $\begin{array}{l}\text { Conservation } \\
\text { Priority }\end{array}$ & - & - & - & - & - & - & - & - & - \\
\hline Boca da Barra Norte & 1110 & High & 4 & 1 & 4 & 2 & 0 & 4 & 4 & 1 & 4 \\
\hline Castelhanos & 1092 & High & 3 & 2 & 0 & 0 & 0 & 2 & 4 & 4 & 2 \\
\hline Moreré & 944 & High & 2 & 4 & 2 & 4 & 4 & 4 & 4 & 1 & 0 \\
\hline Tassimirim & 877 & High & 3 & 3 & 1 & 4 & 2 & 2 & 0 & 1 & 1 \\
\hline Boca da Barra Sul & 866 & High & 3 & 3 & 1 & 3 & 1 & 4 & 4 & 1 & 1 \\
\hline Massabuçu & 673 & Intermediate & 2 & 1 & 1 & 2 & 0 & 4 & 4 & 1 & 2 \\
\hline Caitá & 535 & Intermediate & 2 & 2 & 3 & 4 & 2 & 0 & 4 & 0 & 0 \\
\hline Cais & 167 & Low & 1 & 0 & 4 & 2 & 0 & 4 & 4 & 0 & 0 \\
\hline Mateus & 97 & Low & 0 & 0 & 3 & 1 & 0 & 4 & 4 & 0 & 0 \\
\hline
\end{tabular}




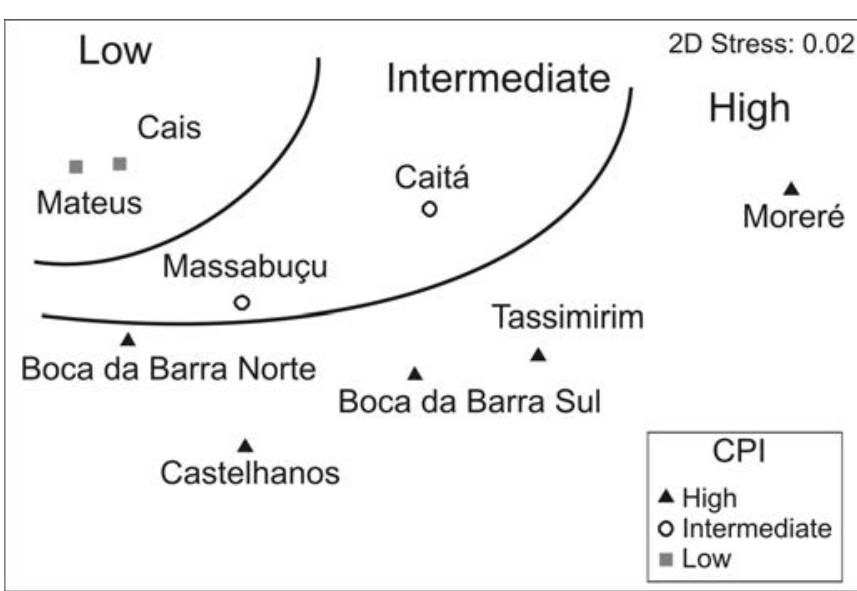

Figure 2 - MDS diagram representative of stations classified as reefs of high, intermediate and low priority for conservation according to benthic organisms coverage, index of coral richness and average age of coral colonies. Caitá = Ilha do Caitá; BBNorte = Boca da Barra Norte; BBSul = Boca da Barra Sul; Tass = Tassimirim; PMor = Piscinas de Moreré; Mass = Massabuçu; Mat = Mateus and PCast $=$ Ponta dos Castelhanos station.

Figura 2 - Diagrama MDS apresentando o agrupamento das estações classificadas como recifes de alta, intermediária e baixa prioridade de conservação de acordo com o percentual de cobertura de organismos bentônicos e com os indices de riqueza de espécies de coral e de idade média recifal. Caitá = Ilha do Caitá; BBNorte = Boca da Barra Norte; BBSul = Boca da Barra Sul; Tass = Tassimirim; PMor = Piscinas de Moreré; Mass = Massabuçu; Mat = Mateus e PCast $=$ Ponta dos Castelhanos.

ers, were defined as rigorous protection zones ('Zonas de Proteção Rigorosa'), a category that restricts anthropogenic activities that result in damage to the ecosystem and allows tourism, research and fishing by traditional communities in a controlled manner (Conder, 1998).

For developing and implementing a management plan that enables more efficient environmental planning and management, quantitative and qualitative knowledge of the natural resources and human activities undertaken in an area are required (Fernandez et al., 2005, 2009). Despite recognition of the value of coral reefs in the current management plan, no study to describe the ecosystem in detail had been conducted. A detailed description enables an evaluation of the health of the environment in question and, consequently, the definition of priority areas for conservation (DeVantier et al., 1998; Beger et al., 2003). In the present study, the ecological status of the reefs was assessed according to a number of attributes related to the reef's benthic community in addition to indicators of the mean age of the reefs and quantitative indices associated with the richness of the coral fauna, as suggested by Cruz et al. (2013). From the results, it was possible to identify the areas where, based on these ecological descriptors, it is most advantageous to invest in conservation. According to Cruz et al. (2013), the indices used here were effective in defining priority areas for conservation of the reefs in Todos os Santos Bay (TSB). Nevertheless, the authors emphasize that the indices should not be interpreted as indicative of preserved or degraded reefs because the indices are related only to the current state of conservation of these environments. It is noteworthy that the three criteria adopted are complementary, thus offering a more complete assessment of environmental quality, as because each index evaluated the reefs based on different ecological parameters.

In the specific case of Brazilian reefs, ecosystems that remain understudied, the use of criteria associated with bio-construction (an index of mean reef age) may skew the results of the computed indices due to the lack of knowledge about the growth rates of some reef-building species (e.g., Porites astreoides, P. branneri and Millepora alcicornis) because the estimate of accumulated ages of colonies is based on previously described colony sizes and growth rates (Cruz et al., 2013). Nevertheless, for the reefs studied here, the most abundant species are exactly those with known annual growth rates: Mussismilia braziliensis, M. hispida, M. harttii, Montastraea cavernosa and Siderastrea spp. (Suggett et al., 2012), which represent approximately $86 \%$ of the estimated coral cover of the sampled reefs. Among the species with unknown growth rates that were recorded, M. alcicornis was the only species that showed a significant percentage of cover (12\%). Greater knowledge of Brazilian reefs, especially in relation to the ecology of native coral species, is thus required so that corals can be optimally used as good models and ecological indicators in conservation studies.

Based on the 9 attributes considered in the calculation of the CPI and in the qualification of the conservation priority status of reefs (high, intermediate or low), attention should focus on establishing NTZs in the highpriority reefs of Boca da Barra Norte, Ponta dos Castelhanos, Piscinas de Moreré, Tassimirim and Boca da Barra Sul because the efficiency of an NTZ is directly associated with the environmental quality of the area (Roberts et al., 2003b). With the establishment of NTZs, these reefs can function as repositories of reef marine life (McClanahan et al., 1999; McClanahan, 2006), acting directly in the recovery of reefs that today are under more pronounced states of degradation, such as reefs of intermediate conservation value (Massabuçu and Caitá) and reefs classified as low priority for conservation (Cais and Mateus).

The recovery of these reefs is directly related to compliance with the standards presented in the management plan prepared for the islands' EPA (Conder, 1998), which prohibits destructive human use, such as the practices of overfishing and destructive tourism. These areas would also benefit from the establishment of 
NTZs, which would serve to enable the recovery of depleted reef stocks (Edmunds \& Carpenter, 2001; Pandolfi et al., 2003; West \& Salm 2003; Bellwood et al., 2004). Two central objectives have motivated the establishment of most marine reserves: conservation and sustainable supply for human use. Conservation objectives include, among others, (1) biodiversity conservation, (2) conservation of rare species and species with restricted distributions, (3) conservation of genetic diversity, (4) preservation and/or restoration of natural ecosystems at a local and regional scale and (5) conservation of areas vital to vulnerable life stages. Humanuse objectives include (1) management of fish stocks (using protected areas to sustain or increase production, restore or rebuild stocks of overexploited species and provide insurance against management failures), (2) recreation, (3) education, (4) research and (5) aesthetic requirements (Roberts et al., 2003a; Roberts et al., 2003b). The Tinharé and Boipeba Islands EPA includes as goals both the conservation and sustainable use of the natural resources by the human population (Conder, 1998). However, the minimum degree of protection (without excluding use) is not the best way to meet these goals.

There are different types of marine protected areas (MPAs) around the world, and each type is associated with different levels of protection and use and is implemented through different institutional arrangements. A MPA can be established to support multiple uses, including the establishment of areas of complete exclusion within the span of the EPA. Some authors consider that at least one NTZ is essential to implement a MPA to achieve the goals of biodiversity conservation and restoration of stocks (Aronson \& Precht, 2006; McClanhan et al., 2006; Kalikoski, 2007).

To accomplish this objective within the Tinharé and Boipeba Islands EPA, the area should be covered with at least two NTZs. The establishment of the two areas is justified because of the spatial extent of the area where the reefs are located. The distance between the stations that marked the northernmost and southernmost sampled points, is approximately $35 \mathrm{~km}$. Shanks et al. (2003) state that two NTZs should be separated by a maximum distance of $20 \mathrm{~km}$ and that exceeding this distance prevents the connection between adjacent benthic populations based on propagule dispersal (spores, eggs and larvae). According to the authors, for NTZs to act as areas of restoration and maintenance of marine diversity, the areas should be circular or rectangular with dimensions between 12.7 and $28.3 \mathrm{~km}^{2}$. Moura et al. (2007) suggested the establishment of an NTZ of $18.5 \mathrm{~km}^{2}$ in the Corumbau Extractive Reserve (Reserva Extrativista de Corumbau, extreme south of Bahia, Brazil), which has shown good results related to the recovery of overexploited fishing resources.
The size and location of the two NTZs proposed for the Tinharé and Boipeba Islands EPA must take into account not only the ecological traits of the sampled reefs but also the use that the local community makes of the region (mainly fishing and tourism) in an attempt to preserve the major reefs with minimal interference in the lives of local people. We therefore suggest two rectangular no-taken zones for the EPA in question (Shanks et al., 2003), each approximately $12 \mathrm{~km}^{2}$, which is the minimum viable size suggested by Shanks et al. (2003), with one located on the island of Tinharé and the other in Boipeba. Of the five reefs classified as high conservation priority, two are extensively used by local populations, mainly through the extraction of fish (Tassimirim and Piscinas de Moreré) and tourism (Piscinas de Moreré) (M. Loiola, personal communication). In an investigative study conducted on the reefs of Piscinas de Moreré, Albu-querque et al. (2014) assessed the impact of tourism on the reef fish communities and estimated the presence of hundreds of tourists daily at this reef station. Therefore, the exclusion of human use in these reefs would involve a conflict with the social groups that use the environments as sources of goods and services. However, the other three reefs classified as high con-servation priority, two located on the Island of Tinharé (Boca da Barra Norte e Boca da Barra Sul) and one located in Boipeba (Ponta dos Castelhanos), must be included in any NTZ established. These two areas are separated by a distance of less than $20 \mathrm{~km}$, which, according to Shanks et al. (2003), would enable connectivity between the benthic populations. We emphasize that based on this design (NTZs of $12 \mathrm{~km}^{2}$ ), at most one strip of $12 \mathrm{~km}$ from a total of almost $40 \mathrm{~km}$, which is the coastal extent of the Tinhare and Boipeba islands, would be closed to human use.

Connectivity with other ecosystems, such as mangroves and algal banks, is critical for coral reefs. As dynamic systems, reef environments must be connected to adjacent reefs and associated ecosystems, which act as external sources of resources, such as larvae and juveniles of benthic and nektonic groups. In addition, many key processes, such as reproduction and recruitment, occur at a scale that exceeds the limits of a single reef (Nyström et al., 2000; Cruz, 2008; Moura et al., 2011). Coral reefs, algal banks and mangroves are not, therefore, independent units but are part of ecologically and hydrodynamically interrelated processes in the marine environment (Nyström et al., 2000; Moberg \& Ronnback, 2003).

Therefore, ensuring both the connectivity and conservation of reef environments and their associated marine ecosystems is essential to ensure the protection of this rich deposit of marine biodiversity. Mangroves, in particular, are considered sources of a variety of natural resources and ecological services and also serve as a 
temporary habitat for a large portion of the fauna associated with reef environments, which depend on mangroves during at least some stage of their life cycles (Moberg \& Ronnback, 2003; Moura et al., 2011). Mangroves are widely represented in the Tinhare and Boipeba Islands EPA and like the coral reefs are considered by the existing management plan to be rigorousprotection zones (Conder, 1998). Therefore, it is essential to ensure the conservation of mangroves to guarantee the resilience of reefs and fishery sustainability (Nyström et al., 2000; Moberg \& Ronnback, 2003).

Simply creating conservation units does not guarantee their effectiveness in the protection of biodiversity. Effective protection requires the responsible managing body to establish appropriate infrastructure, personnel and land regulations that protect the area. Good management plans, appropriate to the reality of the location, are also an important tool for the implementation of CUs (Artaza-Barrios \& Schiavetti, 2007). Tissot et al. (2003) demonstrated through their work in Hawaii that well-established protected areas are fundamental in the protection and conservation of biodiversity.

Proper management of the Tinharé and Boipeba Islands EPA should focus on strict prohibition of human use within NTZs and on the control of water quality and of destructive tourism and fisheries practices over the entire EPA. Local participation should be a focus of the management of the unit because several studies (e.g.,

\section{Acknowledgements}

Data of video transects were originally obtained for the Environmental Impact Assessment Report (EIA) prepared by ENSR International for the El Paso Oil \& Gas of Brazil Ltda. Financial support was provided by the Long-Term Ecological Program (PELD) Site 29 (CNPq \#558.191/2009-6).

ML and ICSC received graduate scholarship from CNPq and RKPK and ZMANL benefit from $\mathrm{CNPq}$ Grants.

\section{References}

Albuquerque, T.; Loiola, M.; Nunes, J.A.C.C.; Reis-Filho, J.A.; Sampaio, C.L.S.; Leduc, A.O.H.C. (2014) - In situ effects of human disturbances on coral reef-fish assemblage structure: temporary and persisting changes are reflected as a result of intensive tourism. Marine and Freshwater Research [published on-line before inclusion in an issue]. DOI: 10.1071/MF13185.

Aronson, R.B.; Precht, W.F. (2006) - Conservation, Precaution, and Caribbean Reefs. Coral Reefs, 25(3):441-450. DOI: 10.1007/ s00338-006-0122-9

Artaza-Barrios, O.H.; Schiavetti, A. (2007) - Análise da Efetividade do Manejo de duas Áreas de Proteção Ambiental do Litoral Sul da Bahia. Revista de Gestão Costeira Integrada, 7(2):117-128. DOI: $10.5894 / \mathrm{rgci} 13$.

Beger, M.; Jones, G.P.; Munday, P.L. (2003) - Conservation of coral reef biodiversity a comparison of reserve selection producers for corals and fishes. Biological Conservation, 111(1):53-62. DOI: 10.1016/S0006-3207(02)00249-5.

Bellwood, D.R.; Hughes, T.P.; Folke, C.; Nystrom, M. (2004) Confronting the Coral Reef Crisis. Nature, 429:827-833. DOI: 10.1038/nature02691.
Kalikoski, 2007 and Moura et al., 2007) indicate that the efficiency of conservation units is directly related to the degree of participation by the local population. These types of measures will enable both the conservation and the recovery of the reefs studied, allowing for the future sustainable use of resources.

\section{Conclusions}

Overall, the coral reefs of the Tinhare and Boipeba islands have similar benthic community composition and structure, with high percentages of algal cover (especially macroalgae) and a satisfactory percentage, by Brazilian reef standards, of reef-building corals. Considering the conservation priority index (CPI), the BBNorte, PCast, PMor, Tas and BBSul reefs (in descending order) had the highest CPIs and therefore represent the best areas for the establishment of NTZs. However, the intensive use of the PMor and Tas reefs (Boipeba) by local people complicates the implementation of NTZ systems. The large spatial extent of the EPA, which includes the sampled reefs $(35 \mathrm{~km})$, justifies the creation of two NTZs. We recommend the establishment of two rectangular areas covering approximately $12 \mathrm{~km}^{2}$ of the BBNorte and BBSul reefs (Tinharé) and PCast reef (Boipeba). With this design, only $30 \%$ of the coastline of the Tinhare and Boipeba islands would be protected by the exclusion of human use.

Acknowledgments are due to the valuable collaboration of Leo XC Dutra for his help with data collection and Rafael C Carvalho and Pedro M Meireles with the production of illustrative maps.

The authors integrate the Reef Ecosystems Work Group of the INCT Ambientes Marinhos Tropicais (InctAmbTropic - CNPq \#565.054/2010-4).

Bryant, D.; Burke, L.; McManus, J; Spalding, M. (1998) - Reefs at Risk: A Map-Based Indicator of Threats to the World's Coral Reefs. 56p., World Resources Institute (WRI) / International Center for Living Aquatic Resources Management (ICLARM) / World Conservation Monitoring Centre (WCMC) / United Nations Environment Programme (UNEP) / World Resource Institute, Washington, DC, USA. ISBN: 1559632574. Availabte on-line at http://coralreef.noaa.gov/aboutcrcp/strategy/reprioritization/ wgroups/resources/climate/resources/reefsatrisk.pdf.

Carleton, C.B.; Done, T.J. (1995) - Quantitative Video Sampling of Coral Reef Benthos: Large-Scale Application. Coral Reefs, 14(1):35-46. DOI: 10.1007/BF00304070.

Clarke, K.R.; Warwick, R.M. (2001) - Changes in Marine Communities: An Approach to Statiscal Analysis an Interpretation. 234p., Plymouth Marine Laboratory, Plymouth, United Kingdom. ISBN: 13: 978- 1855311404.

CONDER. (1998) - Plano de Manejo: APA das Ilhas de Tinharé e Boipeba. Governo de Estado da Bahia. Secretária do Planejamento, Ciência e Tecnologia, Centro de recursos ambientais (CRA.), Salvador, Bahia, Brasil. 
Connell, J.H. (1978) - Diversity in tropical rain forests and coral reefs. Science, 199(4335):1302-1310. DOI: 10.1126/science. 199.4335.1302.

Constanza, R.; d'Arge ,R.; de Groot, R.; Farber, S.; Grasso, M.; Hannon, B.; Limburg, K.; Naeem, S.; O’Neill, R.V.; Paruelo, J.; Raskin, R.G.; Sutton, P; van den Belt, M. (1997) - The value of the world's ecosystem services and natural capital. Nature, 387: 253-260. DOI: $10.1038 / 387253 \mathrm{a} 0$.

Cruz, I.C.S.; Kikuchi, R.K.P.; Leão, Z.M.A.N. (2008) - Use of Video Transect Method for Characterizing the Itacolomis Reefs, Eastern Brazil. Brazilian Journal of Oceanography, 56(4):271280. DOI: $10.1590 / \mathrm{S} 1679-87592008000400002$.

Cruz, I.C.S.; Kikuchi, R.K.P.; Leão, Z.M.A.N.; Done, T.J. (2013) Reef quality criteria for marine reserve selection: an example from eastern Brazil. Aquatic Conservation: Marine and Freshwater Ecosystem, Early View (Online Version of Record published before inclusion in an issue). DOI: 10.1002/aqc.2417.

Cruz, I.C.S.; Kikuchi, R.K.P.; Longo, L.L.; Creed, J.C. (2014) Evidence of a phase shift to Epizoanthus gabrieli Carlgreen, 1951 (Order Zoanthidea) and loss of coral cover on reefs in the Southwest Atlantic. Marine Ecology, Early View (Online Version of Record published before inclusion in an issue). DOI: 10.1111/maec.12141.

DeVantier, L.M.; De'ath, G.; Done, T.J.; Turak, E; 1998 Ecological assessment of a complex natural system a case study from the Great Barrier. Reef. Ecological Applications, 8(2):480496. DOI: 10.1890/1051-0761(1998)008\%5B0480:EAOACN\% 5D2.0.CO;2.

Diaz, M.C.; Rützler, K. (2001) - Sponges: an essential component of Caribbean coral reefs. Bulletin of Marine Science, 69(2): 535546. Available on-line at http://docserver.ingentaconnect.com/ deliver/connect/umrsmas/00074977/v69n2/s26.pdf?expires $=139723709$ $6 \&$ id $=77838861 \&$ titleid $=10983 \&$ accname $=$ Guest + User \& checksum $=4 B$ 5438FA5BD59A3E1E0371FA26C64FE7

Done, T.J. (1992) - Phase shifts in coral reefs and their ecological significance. Hydrobiologia, 80:121-132. DOI: 10.1007/97894-017-3288-8 13.

Done, T.J. (1995) - Ecological criteria for evaluating coral reefs and their implications for managers and researchers. Coral Reefs, 14(4):183-192. DOI: 10.1007/BF00334340.

Edmunds, P.J.; Carpenter, R.C. (2001) - Recovery of Diadema antillarum reduces macroalgal cover and increases abundance of juvenile corals on a Caribbean reef. Proceedings of the National Academy of Sciences, 98(9):5067-5071. DOI: 10.1073/ pnas.071524598.

Fernandes, L.; Day, J.; Lewis, A.; Slegers, S.; Kerrigan, B.; Breen, D.; Cameron, D.; Jago, B.; Hall, J.; Lowe, D.; Innes, J.; Tanzer, J.; Chadwick, V.; Thompson, L.; Gorman, K.; Simmons, M.; Barnett, B.; Sampson, K.; De'ath, G.; Mapstone, B.; Marsh, H.; Possingham, H.; Ball, I.; Ward, T.; Dobbs, K.; Aumend, J.; Slater, D.; Stapleton, K. (2005) - Establishing Representative No-Take Areas in the Great Barrier Reef: Large-Scale Implementation of Theory on Marine Protected Areas. Conservation Biology, 19(6):1733-1744. DOI: 10.1111/j.15231739.2005.00302.x.

Fernandes, L.; Day, J.; Kerrigan, B.; Breen, D.; De'ath, G.; Coles, R.; Done, T.; Marsh. H.; Poiner, I.; Ward, T.; Williams, D.; Kenchington, R. (2009) - A process to design a network of marine no-take areas: Lessons from the Great Barrier Reef. Ocean \& Coastal Management, 52(8):439-447. DOI: 10.1016/j.ocecoaman.2009.06.004.

Francini-Filho, R.B.; Moura, R.L. (2008) - Dynamics of fish assemblages on coral reefs subjected to different management regimes in the Abrolhos Bank, eastern Brazil. Aquatic Conservation: Marine and Freshwater Research, 18(7):11661179. DOI: $10.1002 /$ aqc. 966 .
Halpern, B.S. (2003) - The Impact of Marine Reserves: Do Reserves Work and Does Reserve Size Matter? Ecological Applications, 13(1):117-137. DOI: 10.1890/1051-0761(2003)013[0117:TIOM RD]2.0.CO;2.

Hetzel, B.; Castro, C.B. (1994) - Corais do Sul da Bahia. 189 p., Nova Fronteira, Rio de Janeiro, Rio de Janeiro. ISBN: 978-8516068820 .

Hoegh-Guldberg, O. (2006) - Complexities of coral reef recovery. Science, 311(5757):42-43. DOI: 10.1126/science.1122951.

Hughes, T.P. (1994) - Catastrophes, phase shifts, and large-scale degradation of Caribbean coral reefs. Science, 265(5178):15471551. DOI: $10.1126 /$ science.265.5178.1547.

Hughes, T.P.; Bellwood, D.R.; Connolly, S.R. (2002) - Biodiversity hotspots, centres of endemicity, and the conservation of coral reefs. Ecology Letters, 5(6):775-784. DOI: 10.1046/j.14610248.2002.00383.x.

Jackson, J.B.C.; Kirby, M.X.; Berger, W.H.; Bjorndal, K.A.; Botsford, L.W.; Bourque, B.J.; Bradbury, R.H.; Cooke, R.; Erlandson, J.; Estes, J.A.; Hughes, T.P.; Kidwell, S.; Lange, C.B.; Lenihan, H.S.; Pandolfi, J.M.; Peterson, C.H.; Steneck, R.S.; Tegner, M.J.; Warner, R.R. (2001) - Historical overfishing and the recent collapse of coastal ecosystems. Science, 293(5530):629-638. DOI: 10.1126/science.1059199.

Jameson, S.C.; Erdmann, M.V.; Gibson Jr., G.R.; Pott, K.W. (1998) - Development of Biological Criteria for Coral Reef Ecosystem Assessment. 79p., United States Environmental Protection Agency, Office of Science and Technology, Health and Ecological Criteria Division, Washington, DC, United States. Available online in: http://www.epa.gov/owow/oceans/coral.

Jompa. J.; McCook, L.J. (2002) - Effects of competition and herbivory on interactions between a hard coral and a brown alga. Journal of Experimental Biology and Ecology, 271(1): 2539. DOI: 10.1016/S0022-0981(02)00040-0.

Kalikoski, D.C. (2007) - Áreas Marinhas Protegidas, Conservação e Justiça Social: Considerações à Luz da Teoria dos Comuns. In: Ana F. Caminha; Ana P. Prates; Ângela E. M. Duarte; Danielle Blanc; João L. F. Ferreira; Maria C. Hazin; Mariana S. Viana; Paula M. Pereira (eds.), Áreas Aquáticas Protegidas como Instrumento de Gestão Pesqueira, Série Áreas protegidas do Brasil 4, pp. 65-77, Ministério do Meio Ambiente, Secretaria de Biodiversidade e Florestas, Núcleo de Zona Costeira e Marinha, Brasília, Brazil. ISBN 978-8577380770.

Khalaf, M.A.; Kochzius, M. (2002) - Changes in trophic community structure of shore fishes at an industrial site in the Gulf of Aqaba, Red Sea. Marine Ecology Progress Series, 239: 287299. DOI: $10.3354 /$ meps 239287.

Knowlton, N.; Jackson, J.B.C. (2001) - The ecology of coral reefs. In: Mark D. Bertness; Steve D. Gaines; Mark E. Hay (eds.), Marine Community Ecology, pp. 395-422, Sinauer Associates, Sunderland, Massachusets, United States. ISBN: 0878930574550.

Leão, Z.M.A.N.; Kikuchi, R.K.P.; Testa, V. (2003) - Corals and Coral Reefs of Brazil. In: Jorge Cortés (ed.), Latin American Coral Reefs, pp. 9-52, Elsevier B.V., Amsterdam, Netherlands. ISBN: 0444513884.

Leão, Z.M.A.N.; Kikuchi, R.K.P. (2005) - A relic coral fauna threatened by global changes and human activities, Eastern Brazil. Marine Pollution Bulletin, 51(5-7):599-611. DOI: 10.1016/j.marpolbul.2005.04.024.

Leão, Z.M.A.N.; Dutra, L.X.C.; Spanó, S. (2006) - The characteristics of bottom sediments. In: Guilherme F. Dutra; Gerald R. Allen; Timothy Werner; Sheila A. McKenna (eds.), $A$ Rapid Marine Biodiversity Assessment of Abrolhos Bank, Bahia, Brazil, pp. 75-81, Conservation International, Washington DC, United States. ISBN: 1881173941. 
Lirman, D. (2001) - Competition between macroalgae and corals: effects of herbivore exclusion and increased algal biomass on coral survivorship and growth. Coral Reefs, 19(4):392-399. DOI: $10.1007 / \mathrm{s} 003380000125$.

Loiola, M.; Oliveira, M.D.M.; Kikuchi, R.K.P. (2013) - Tolerance of Brazilian brain coral Mussismilia braziliensis to sediment and organic matter inputs. Marine Pollution Bulletin, 77(1-2):55-62. DOI: 10.1016/j.marpolbul.2013.10.033.

McClanahan, T.R.; Muthiga, N.A.; Kamukuru, A.T.; Machano, H.; Kiambo, K.W. (1999) - The effects of marine parks and fishing on coral reefs of northern Tanzania. Biological Conservation, 89(2):161-182. DOI: 10.1016/S0006- 3207(98)00123-2.

McClanahan, T.R.; Marnane, M.J.; Cinner, J.E.; Kiene W.E. (2006) - A Comparison of Marine Protected Areas and Alternative Approaches to Coral-Reef Management. Current Biology, 16(14):1408-1413. DOI: 10.1016/ j.cub.2006.05.062.

McCook, L.J. (1999) - Macroalgae, nutrients and phase shifts on coral reefs: Scientific issues and management consequences for the Great Barrier Reef. Coral Reefs, 18(4): 357-367. DOI: $10.1007 / \mathrm{s} 003380050213$.

McCook, L.J.; Jompa, J.; Diaz-Pulido, G. (2001) - Competition between coral and algae on coral reefs: a review of evidence and mechanisms. Coral Reefs, 19(4): 400-417. DOI: 10.1007/s003380000129.

McField, M.D.; Hallock, P.; Jaap, W.C. (2001) - Multivariate Analysis of Reef Community Structure in the Belize Barrier Reef Complex. Bulletin of Marine Science, 69(2):745-758. Available online in: http://docserver.ingentaconnect.com/deliver/ connect/umrsmas/00074977/v69n2/s40.pdf?expires $=1397239662 \& \mathrm{id}=7$ 7839178\&titleid $=10983 \&$ accname $=$ Guest + User\&checksum $=$ EC1B4F6 E1092B76693C3DD0755CF3398

Moberg, F.; Folke, C. (1999) - Ecological goods and services of coral reef ecosystems. Ecological Economics, 29(2):215-233. DOI: 10.1016/S0921-8009(99)00009-9.

Moberg, F.; Rönnbäck, P. (2003) - Ecosystem services of the tropical seascape: Interactions, substitutions and restoration. Ocean and Coastal Management, 46(1-2): 27-46. DOI: 10.1016/S0964-5691(02)00119-9.

Moura, R.L. (2002). Brazilian reefs as priority areas for biodiversity conservation in the Atlantic Ocean. Proceedings of the 9th International Coral Reef Symposium, 2; 917-920. Available online in: http//www.coremap.or.id/downloads/ICRS9-tha_Moura.pdf

Moura, R.L.; Dutra, G.F.; Francini-Filho, R.B.; Minte- Vera, C.V.; Curado, I.B.; Guimarães, F.J.; Oliveira, R.F.; Alves, D.C. (2007) - Gestão do Uso de Recursos Pesqueiros na reserva Extrativista Marinha do Corumbau - Bahia. In: Ana F. Caminha; Ana P. Prates; Ângela E. M. Duarte; Danielle Blanc; João L. F. Ferreira; Maria C. Hazin; Mariana S. Viana; Paula M. Pereira (eds.), Áreas Aquáticas Protegidas como Instrumento de Gestão Pesqueira, Série Áreas protegidas do Brasil 4, pp. 179-191, Ministério do Meio Ambiente, Secretária de Biodiversidade e Florestas, Núcleo de Zona Costeira e Marinha, Brasília, Brazil. ISBN 978-8577380770.

Moura, R.L.; Francini-Filho, R.B.; Chaves, E.M.; Minte-Vera, C.V.; Lindeman, K.C. (2011) - Use of riverine through reef habitat systems by dog snapper (Lutjanus jocu) in eastern Brazil. Estuarine, Coastal and Shelf Science, 95(1):274-278. DOI: 10.1016/j.ecss.2011.08.010.

Mumby, P.J. (2006) - The Impact of Exploiting Grazers (Scaridae) on The Dynamics of Caribbean Coral Reefs. Ecological Applications, 16(2):747-769. DOI: 10.1890/1051- 0761.

Negri, A.P.; Webster, N.S.; Hill, R.T.; Heyward, A.J. (2001) Metamorphosis of broadcast spawning corals in response to bacteria isolated from crustose algae. Marine Ecology Progress Series, 223(1):121-131. DOI: 10.3354/meps223121.
Neves, E.G.; Andrade, S.C.; Silveira, F.L.; Solferini, V.N. (2008) Genetic Variation and Population Structuring in two Brooding Coral Species (Siderastrea Stellata and Siderastrea Radians) from Brazil. Genetica, 132(3):243-254. DOI: 10.1007/s10709007-9168-z.

Norström, A.V.; Nyström, M.; Lokrantz, J.; Folke, C. (2009) Alternative states on coral reefs: beyond coral-macroalgal phase shifts. Marine Ecology Progress Series, 376:295-306. DOI: 10.3354/meps07815

Nughes, M.M.; Roberts, C.M. (2003) - Coral mortality and interaction with algae in relation to sedimentation. Coral Reefs, 22(4):507-516. DOI: 10.1007/s00338-003-0338-x.

Nughes, M.M.; Smith, G.W.; van Hooidonk, R.J.; Seabra, M.I.; Bak, R.P.M. (2004) - Algal contact as a trigger for coral disease. Ecology Letters, 7(10):919-923. DOI: 10.1111/j.14610248.2004.00651.x.

Nyström, M.; Folke; C.; Moberg, F. (2000) - Coral reef disturbance and resilience in a human-dominated environment. Trends in Ecology and Evolution, 15(10):413-417. DOI: 10.1016/S01695347(00)01948-0.

Nyström, M.; Graham, N.A.J.; Lokrantz, J.; Norström, A.V. (2008) - Capturing the cornerstones of coral reef resilience: linking theory to practice. Coral Reefs, 27(4):795-809. DOI: 10.1007/s00338-008-0426-z.

Pandolfi, J.M.; Bradbury, R.H.; Sala, E.; Hughes, T.P.; Bjorndal, K.A.; Cooke, R.G.; McArdle, D.; McClenachan, L.; Newman, M.J.H.; Paredes, G.; Warner, R.R.; Jackson, J.B.C. (2003) Global Trajectories of the Long-Term Decline of Coral Reef Ecosystems. Science, 301(5635): 955-958. DOI: 10.1126/ science. 1085706.

Reaka-Kudla, M.L. (1997) - The global biodiversity of coral reefs: a comparison with rain forests. In: Marjorie L. Reaka-Kudla; Don E. Wilson; Edward O. Wilson (eds.), Biodiversity II: Understanding and Protecting our Biological Resources, pp. 83-108, Joseph Henry Press, Washington, DC, United States. ISBN: 0-309-05227-0.

Riegl, B.; Luke, K.E. (1998) - Ecological Parameters of Dynamited Reefs in the Northern Red Sea and their Relevance to Reef Rehabilitation. Marine Pollution Bulletin, 37(8-12):488-489. DOI: 10.1016/S0025-326X(99)00104-6.

Roberts, C.M.; Andelman, S.; Branch, G.; Bustamante, R.H.; Castilla, J.C.; Dugan, J.; Halpern, B.S.; Lafferty, K.D.; Leslie, H.; Lubchenco J.; Deborah, M.; Possingham, H.P.; Ruckelshaus, M.; Warner, R.R. (2003a) - Ecological criteria for evaluating candidate sites for marine reserves. Ecological Applications, 13(1):199-214. DOI: 10.1890/1051-0761(2003)013[0199: ECFECS]2.0.CO;2.

Roberts, C.M.; Branch, G.; Bustamante, R.H.; Castilla, J.C.; Dugan, J.; Halpern, B.S.; Lafferty, K.D.; Leslie, H.; Lubchenco, J.; McArdle, D.; Ruckelshaus, M.; Warner, R.R. (2003b) Application of ecological criteria in selecting marine reserves and developing reserve networks. Ecological Applications, 13(1):215-228. DOI: 10.1890/1051-0761(2003)013[0215: AOECIS]2.0.CO;2.

Salm, R.V.; Clark, J.R.; Siirila, E. (2000) - Marine and Coastal Protected Areas: A Guide for Planners and Managers, 371p., joint publication by International Union for Conservation of Nature and Natural Resource, Washington DC, United States. ISBN: 2831705401.

Shanks, A.L.; Grantham, B.A.; Carr, M.H. (2003) - Propagule Dispersal Distance and the Size and Spacing of Marine Reserves. Ecological Applications. 13(1):159-169. DOI: 10.1890/1051-0761(2003)013\%5B0159:PDDATS\%5D2.0.CO;2 
Silva, M. (2005) - The Brazilian Protected Areas Program. Conservation Biology. 19(3):608-611. DOI: 10.1111/j.15231739.2005.00707.x

Souter, D.W.; Lindén, O. (2000) - The Health and Future of Coral Reef Systems. Ocean \& Coastal Management, 43(8-9):657-688. DOI: 10.1016/S0964-5691(00)00053-3.

Spalding, M.D. (2000) - Spatial Variation in Coral Reef Fish Biodiversity at Intermediate Scales Arround Oceanic Islands. Proceedings 9th International Coral Reef Symposium, 1: 23-27. Available on-line at http://www.researchgate.net/publication /228452786_Spatial_variation_in_coral_reef_fish_biodiversity_at_inter mediate_scales_around_oceanic_islands.

Suchanek, T.H.; Green, D.J. (1981) - Interspecific competition between Palythoa caribaeorum and other sessile invertebrates on St. Croix Reefs, US Virgin Islands. Proceedings of the 4th International Coral Reef Symposium 2: 679-684. Available online at http://www.aoml.noaa.gov/general/lib/CREWS/Cleo/St.Croix /salt_river85.pdf.

Suggett, D.; Kikuchi, R.K.P.; Oliveira, M.D.M.; Spanó, S.; Carvalho, R.; Smith, D.J. (2012) - Photobiology of corals from Brazil's near-shore marginal reefs of Abrolhos. Marine Biology, 159(7):1461-1473. DOI: 10.1007/s00227-012-1925-6.

Tanner, J.E. (1997) - The effects of density on the Zoanthid Palythoa caesia. Journal of Animal Ecology, 66(6):793-810. Article Stable URL: http://www.jstor.org/stable/5996

Tissot, B.N.; Walsh, W.J.; Hallacher, L.E. (2003) - The Effectiveness of Marine Protected Areas and the Impacts of Aquarium Fish Collecting in Hawaii. West Hawaii Aquarium Project Technical Report. 22p., joint publication by Hawaii
Coral Reef Initiative, University of Hawaii, Honolulu, Hawai and National Oceanic and Atmosferic Administration (NOAA), Silver Springs, Florida, USA. Available on-line at: http://www. hcri.ssri.hawaii.edu/files/research/pdf/tissot.

Vermeij, M.J.A. (2005) - Substrate composition and adult distribution determine recruitment patterns in a Caribbean brooding coral. Marine Ecology Progress Series, 295:123-133. DOI: $10.3354 / \mathrm{meps} 295123$.

West, J.M.; Salm, R.V. (2003) - Resistance and Resilience to Coral Bleaching: Implications for Coral Reef Conservation and Management. Conservation Biology, 17(4): 956-967. DOI: 10.1046/j.1523- 1739.2003.02055.x.

Wilkinson, C. (ed.) (2008) - Status of Coral Reefs of the Worlds: 2008. 304p., joint publication by Global Coral Reef Monitoring Network and The Australian Institute of Marine Science, Townsville, Queensland, Austrália. ISSN: 1447-6185.

Wood, L.J.; Fish, L.; Laughren, J.; Pauly, D. (2008) - Assessing progress towards global marine protection targets: Shortfalls in information and action. Oryx, 42(3):340-351. DOI: 10.1017/S003060530800046X.

Worm, B.; Barbier, E.B.; Beaumont, N.; Duffy, E.; Folke, C.; Halpern, B.S.; Jackson, J.B.C.; Lotze, H.K.; Micheli, F.; Palumbi, S.R.; Sala, E.; Selkoe, K.A.; Stachowicz, J.J.; Watson, R. (2006) - Impacts of Biodiversity Loss on Ocean Ecosystem Services. Science, 314(5800):787-790. DOI: 10.1126/science. 1132294. 